\title{
Immüno-PET İçin Geliştirilen Zirkonyum-89 (89Zr) Radyofarmasötikleri
}

\section{Zirkonium-89 (89Zr) Radiopharmaceutics Developed for Immuno- PET}

\author{
Burcu Altıparmak Güleç ${ }^{1}$, Fatma Yurt $^{2 *}$ \\ ${ }^{1}$ Barbaros Mah. Şekerpınar Cad. Ceylan Sok. ÇAN-KA Evleri 1. Blok Daire:1, Çanakkale, Merkez. Turkey \\ ${ }^{2}$ Department of Nuclear Applications, Institute of Nuclear Science, Ege University, İzmir, Turkey \\ e-mail: burcu@synapse.com.tr,_ftmyurt@gmail.com, fatma.yurt.lambrecht@ege.edu.tr \\ ORCID: 0000-0001-8078-6960 \\ ORCID: 0000-0002-9394-6908 \\ *Sorumlu yazar/ Corresponding Author: Fatma Yurt \\ Gönderim Tarihi / Received: 14.12.2020 \\ Kabul Tarihi / Accepted: 25.05.2021 \\ DOI: $10.34087 /$ cbusbed.840543
}

\begin{abstract}
$\ddot{O} z$
Kanser dokusunun görüntülenmesinde kullanılan moleküler görüntüleme ajanlarının geliştirilmesi hakkında çok çeşitli ve kapsamlı araştırmalar yapılmaktadır. Pozitron Emisyon Tomografi (PET) radyofarmasötikleri, pozitron yayan bir radyonüklidin ve bir moleküler yapıya bağlanması ile oluşturulur. ${ }^{89} \mathrm{Zr}$-Immüno-PET olarak adlandırılan, ${ }^{89} \mathrm{Zr}$ işaretli monoklonal antikorlar $(\mathrm{mAb})$, peptitler, nanopartiküller, proteinler ve diğer bileşikler kanserli doku görüntülenmesinde kullanılmaktatır. Bu derlemede, uzun yarı ömrü ile Immüno-PET görüntülemede yaygın olarak kullanılan ${ }^{89} \mathrm{Zr}$ radyonüklidi ile işaretli farmasötiklerin son beş yılda yapılan klinik öncesi ve klinik çalışamalardaki potansiyeli gözden geçirilmiş ve tartışılmıştır.
\end{abstract}

Anahtar Kelimeler: İmmüno-PET, moleküler görüntüleme, Radyofarmasötikler, ${ }^{89} \mathrm{Zr}$

\begin{abstract}
A wide variety and comprehensive research are being conducted on the development of molecular imaging agents used in imaging cancer tissue. Positron Emission Tomography (PET) radiopharmaceuticals consist of a positronemitting radionuclide and a molecular structure. ${ }^{89} \mathrm{Zr}$-labeled monoclonal antibodies (mAb), peptides, nanoparticles, proteins, and other compounds, called ${ }^{89} \mathrm{Zr}$-Immuno-PET, have been used in cancerous tissue imaging. In this review, the potential of ${ }^{89} \mathrm{Zr}$ radionuclide-labeled pharmaceuticals, which are widely used in Immuno-PET imaging with their long half-life, in pre-clinical and clinical studies conducted in the last five years were reviewed and discussed.
\end{abstract}

Keywords: Immuno-PET, Molecular imaging, Radiopharmaceutics, ${ }^{89} \mathrm{Zr}$

\section{Giriş}

Kanser, anormal hücrelerin kontrolsüz bir şekilde büyüdüğünde, organlarda veya organ dokusunda gelişen ve diğer organlara yayılabilen (metastaz) bir hastalıkdır. Kanser erken teşhis edildiğinde etkili tedaviye yanıt verme olasılığg daha yüksektir, bu da daha yüksek bir hayatta kalma olasılığının yanı sıra daha az morbidite ve daha ucuz tedavi ile sonuçlanır. Kanserli dokuyu erken tespit etmede tarama en önemli tekniktir. Tarama, bir belirti göstermemiş veya göstermiş anormalliklere tanı koymak ve onları doğru tedavi içinyönlendirmeyi hedeflemektedir [1].
Kanser alanında, kanserli dokunun görüntülenmesinde kullanılan moleküler görüntüleme ajanlarının geliștirilmesi üzerine çok çeşitli ve kapsamlı araștırmalar yapılmıştır ve yapılmaya devam edilmektedir. Görüntülemede bu ajanları kullanmanın avantajı, noninvaziv olmalarıdır. Tümör dokusunu görüntüleyebilmek için yeni teknikler geliştirilmiştir. Bu teknikler; Floresan görüntüleme, manyetik rezonans görüntüleme (MRI), Pozitron Emisyon Tomografisi (PET) veya Tekli Foton Emisyonlu Bilgisayarlı Tomografi (SPECT)'dir. PET ile görüntüleme yönteminde yüksek çözünürlükte 
görüntüler elde edilebildiğinden ve sonuçlar kantitatif olarak değerlendirilebildiğinden tercih sebebidir [2].

Nükleer Tıp'ta PET teknolojisinin klinik tıpba girmesi ve bilgisayarlı tomografi (BT) ile birleştirilmesi (PET/BT) kansere yönelik teşhisin etkinliğini önemli oranda arttırmıştır [3]. PET kamerada görüntü elde edebilmek için radyofarmasötiğin radyonüklid kısmına pozitron yayıc1 (+) olması gerekmektedir. PET radyofarmasötiklerinde küçük molekülleri işaretlemek için elverişli olan radyonüklidler; ${ }^{15} \mathrm{O}\left(\left(\mathrm{t}_{1 / 2}=2 \mathrm{dak}\right.\right.$. $),{ }^{13} \mathrm{~N}$ $\left(\mathrm{t}_{1 / 2}=10\right.$ dak. $),{ }^{11} \mathrm{C}\left(\mathrm{t}_{1 / 2}=20\right.$ dak. $),{ }^{68} \mathrm{Ga}\left(\mathrm{t}_{1 / 2}=68\right.$ dak. $)$ and ${ }^{18} \mathrm{~F} \quad\left(\mathrm{t}_{1 / 2}=110\right.$ dak. $)$ dır [4]. $\mathrm{Bu}$ radyonüklidler kısa yarılanma ömrüne sahip, dokuda hızlı akümülasyon ve temizlenme gösterir. $\mathrm{Bu}$ nedenle geliştirilen bu radyofarmasötikler enjeksiyondan ilk 24 saat içinde görüntüleme sağlar. Bunun yanısıra monoklonal antikorlar gibi büyük moleküllerin görüntülenmesinde yukarıda bahsi geçen radyonüklidler ilegörüntü elde etmek zordur. $\mathrm{Bu}$ büyük moleküllerin vücuttan temizlenme süresi uzun olduğundan onların biyolojik yarı ömürleri ile radyonüklidlerin fiziksel yarı ömürleri birbirleri ile uyumsuzdur. $\mathrm{Bu}$ veriler göz önüne alındığında işaretlemede yarı ömürleri nispeten uzun ${ }^{89} \mathrm{Zr}$ $\left(\mathrm{t}_{1 / 2}: 3,3\right.$ gün$),{ }^{124} \mathrm{I}\left(\mathrm{t}_{1 / 2}: 4,2\right.$ gün $),{ }^{64} \mathrm{Cu}\left(\mathrm{t}_{1 / 2}: 12,7\right.$ saat $),{ }^{86} \mathrm{Y}$ $\left(\mathrm{t}_{1 / 2}: 14,7\right.$ saat) gibi PET izotopları kullanılır [5].

İmmüno-PET olarak adlandırılan pozitron emisyon tomografisinin yeni bir uygulaması, görüntülemede monoklonal antikorları $(\mathrm{mAb})$ ve nanoprobları işaretleyerekkanserli dokuya gönderir. İmmüno-PET görüntülemede $\mathrm{mAb}$ farmakokinetiği ile uyumlu 3,3 günlük yarılanma ömrüne sahip ${ }^{89} \mathrm{Zr}$ radyoizotopu kullanır [6]. ${ }^{89} \mathrm{Zr}$ radyonüklidinin 30 yılı aşkın bir süre önce piyasaya sürülmesi, bu radyonüklid kullanılarak hazırlanan ajanlara olan ilgiyi arttırmıştır [5].

Son beş yılda yapılan klinik ve pre-klinik çalışmalar 1şığında, antikor ve nanopartikül bazlı immüno-PET radyofarmasötiklerine ait potansiyel bu derlemede bir başlık altında toplanmıştır.

\subsection{Zr-89 Radyofarmasötikleri}

Teşhis amacı ile hazırlanan bir radyofarmasötik, üç bişelenden oluşmaktadır: vücutta görüntülenecek bölgeye izotopu gönderen taşıyıcı bir vektör molekül, teşhis uygulamaları için seçilen bir radyonüklid ve arada bağlayıcı bir şelatlayıcı liganddır. Bu vektör molekülleri, inorganik veya biyoaktif bir molekül; peptid, antikorlar, protein, antikor fragmanları veya bir nanopartikülden oluşabilir [7].

${ }^{89} \mathrm{Zr}$-immüno-PET olarak adlandırılan ${ }^{89} \mathrm{Zr}$ işaretli mAb'ler (örneğin; antikor ilaç konjugatları (ADCs), immünoglobulin (IgG)), peptitler (örneğin; RGD peptidleri), nanopartiküller (örneğin; lipozomlar, dekstran parçacıkları, karbon nanotüpler, nanokolloid albümin), proteinler ( örneğin; transferrin, albümin) ve diğer hedeflenen yapılar (örneğin; kök hücreleri,

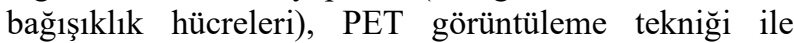
tümörlü hücreye gönderilen radyofarmasötiğin in vivo davranışını, tümörlü hücrelerin görüntülenmesini ve aynı zamanda tedavi sonrası yanıtın görüntülenmesinde kullanılır [8].
${ }^{89} \mathrm{Zr}$ işaretli radyofarmasötiklerin stabilitesini ve radyonüklidin ajandan bağlanmasını sağlamak için şelatörler kullanılabilir. ${ }^{89} \mathrm{Zr}, 3$ hidroksamat grubu aracılığıyla desferrioksamin B (Df veya DFO) başta olmak üzere iki işlevli şelat olan p-izotiyosiyanatobenzildesferrioksamin B (Df-Bz-NCZ) ile de şelatlanabilir. Bunlar dıșında Df'nin amino grubu sırasıyla bromoasetildesferrioksamin (Df-Bac), iyodoasetil-desferrioksamin (Df-lac) ve maleimidosikloheksil-desferrioksamin (DfChx-Mal) çeşitli kimyasallar ile açillenmiştir ve yüksek verimde ${ }^{89} \mathrm{Zr}$ ile işaretlenme gerçekleştirilmiştir [9].

Son 30 y1lda ${ }^{89} \mathrm{Zr}$-PET görüntülemeyle ilgili preklinik ve klinik çalışmaların sayısı önemli derecede artmıştır. 2019 yılının başından beri bu konu ile ilgili 300'den fazla orijinal makale taranmıştır. Bu çalışmaların \%70'inden fazlası antikor ve antikor fragmanlarından oluşur ve sırasıyla bunları nanopartiküller (NP'ler), proteinler, peptitler ve hücreler izler. Gıda ve İlaç Dairesi (FDA) tarafindan onaylanan antikor ve antikor fragmanlarının say1s1 son on yılda 22'den (2010) 93'e (2018) büyük ölçüde artmıştır. Sonuç olarak, insan epidermal büyüme faktörü reseptörü-2 (HER2), epidermal büyüme faktörü reseptörü (EGFR), vasküler endotelyal büyüme faktörüA (VEGF-A), B hücresi yüzey antijeni (CD20) ve prostat spesifik membran antijeni (PSMA) en sık araştırılan hedefler olamak üzere preklinik çalışmaların yanında klinik çalışmalarda da bu radyofarmasötiklerin sayısı hizla artmaktadır [10].

\subsection{Zr-89'un Elde Edilişi ve Özellikleri}

\subsubsection{Zr-89'un Kimyasal ve Fiziksel Özellikleri}

Zirkonyum, 1789 yılında Alman kimyager Martin Heinrich Klaproth tarafindan $\mathrm{ZrSiO}_{4}$ mineral zirkonundan zirkonyum oksitin ayrıştırılmasıyla keşfedilmiştir. Periyodik cetvelin IVB grubu'nda yer alan bir geçiş metali olan zirkonyum sulu çözeltilerdesadece +4 oksidasyonunda bulunur [4].

İmmuno-PET için ideal bir radyonüklid olan ${ }^{89} \mathrm{Zr}$, görüntüleme ve hedeflenme avantajları ile dikkat çeker. $\% 23$ pozitron emisyonu ve \%77 elektron yakalama ile ${ }^{89 m}{ }^{\prime}$ 'ye bozulur ve $\gamma$ 1şını emisyonu (909 keV) ile kararlı ${ }^{89} \mathrm{Y}$ 'ye dönüşür. 3,3 günlük yarı ömüre sahip ${ }^{89} \mathrm{Zr}$ radyonüklidi monoklonal antikorların farmakokinetiği ile kusursuz bir şekilde senkronize olur. Düşük pozitron enerjisine sahip olması yüksek çözünürlükte PET görüntüleri elde edilmesini sağlar. ${ }^{89} \mathrm{Zr}$ kalıntı radyonüklid olma özelliği ${ }^{124}$ I gibi kalıntı olmayan diğer radyonüklidler ile karşılaştırıldığında tümör hücresi içinde hapsolması (tümör retansiyonu) ve tümör/normal doku oranlarının yükssek olması ${ }^{89} \mathrm{Zr}$ 'yi görüntüleme için ideal bir radyonüklid yapar $[9,11]$.

\subsubsection{Zirkonyum-89 Üretimi ve Saflaştırılması}

${ }^{89}{ }^{\prime}$ 'nin doğal kaynaklardan elde edilebilmesi sebebi ile ${ }^{89} \mathrm{Y}(\mathrm{p}, \mathrm{n}){ }^{89} \mathrm{Zr}$ ve ${ }^{89} \mathrm{Y}(\mathrm{d}, 2 \mathrm{n}){ }^{89} \mathrm{Zr}$ reaksiyonlar ${ }^{89} \mathrm{Zr}$ üretmek için en yaygın yöntemdir. ${ }^{89} \mathrm{Y}(\mathrm{d}, 2 \mathrm{n}){ }^{89} \mathrm{Zr}$ reaksiyonunda, ${ }^{89} \mathrm{Zr}$ üretiminde doğal itriyum peletleri kullanılarak, 16 $\mathrm{MeV}$ döteryum 1şını ile ışınlanmış ve iyon değişim kolonunda saflaştırılmıştır. ${ }^{89} \mathrm{Y}(\mathrm{p}, \mathrm{n}){ }^{89} \mathrm{Zr}$ reaksiyonunda ise ${ }^{89} \mathrm{Zr}$ üretiminde itriyum katı hedefi kullanılarak 14 $\mathrm{MeV}$ enerjili bir proton ışını ile bombardıman edilmiştir. $\mathrm{Bu}$ iki üretim yöntemi karşılaştırıldığında, ${ }^{89} \mathrm{Y}(\mathrm{d}, 2 \mathrm{n}){ }^{89} \mathrm{Zr}$ 
reaksiyonu, ${ }^{89} \mathrm{Y}(\mathrm{p}, \mathrm{n}){ }^{89} \mathrm{Zr}$ reaksiyonuna göre daha yüksek verim ile elde edilmesine rağmenküçük ve orta tıbbi siklotronlar ${ }^{89} \mathrm{Y}(\mathrm{d}, 2 \mathrm{n}){ }^{89} \mathrm{Zr}$ reaksiyonu için gerekli olan yüksek enerjili döteronları üretememesi uygulanmasını elverişsiz hale getirir. $\mathrm{Bu}$ nedenle ${ }^{89} \mathrm{Y}(\mathrm{p}, \mathrm{n}){ }^{89} \mathrm{Zr}$ reaksiyonu, ${ }^{89} \mathrm{Zr}$ üretimi için daha kullanışlıdır [3,12]. Bu reaksiyon sonucunda ${ }^{88} \mathrm{Zr}\left(\mathrm{t}_{1 / 2}: 83,4\right.$ gün) ve $\mathrm{k1Z1}{ }^{88} \mathrm{Y}$ $\left(\mathrm{t}_{1 / 2}: 106,6\right.$ gün) safsızlıkları oluşabilir. Bu yüzden proton 1şıma enerjisi 14 MeV'i geçmemelidir. ${ }^{89} \mathrm{Zr}$ 'nin izolasyonu ve saflaştırılması için birçok araştırmalar sonucunda elde edilen verilere göre hidroksamat ile modifiye edilmiş reçine kullanılarak zayıf katyon değişim kromatografisi tercih edilen yöntem olmuştur [13].

\subsection{Zr-89 ile İşaretli PET Radyofarmasötikleri}

PET, siklotronda üretilen radyonüklid kullanılarak tasarlanan radyofarmasötiklerin vücuttaki fonksiyonlarını kantitatif olarak tespit eden non-invaziv bir görüntüleme yöntemidir. BT ise normal ve patolojik dokuların anatomik görüntüsünü oluşturarak kanserli doku tanisı, evrelenmesi ve tedavi sonrasındaki değişiklikleri ortaya koyar. PET/BT, hibrit moleküler görüntüleme yöntemi olup bu iki cihazın birleştirilmesinden oluşmaktadır [14].

PET radyofarmasötiği, moleküler bir yapı (vektör, araç, ligand) ve pozitron yayan bir radyonüklidten oluşmaktadır. Bu iki bileşenin birbirlerinden kopmaması için hücrelerdeki kimyasal ve biyokimyasal etkileşimlerden sorumlu bağlayıcı bir araç kullanılabilir [15]. PET radyofarmasötiğinin etkinliği radyoizotopun yarı ömrü ile bağlanacak moleküler yapının farmakokinetik özelliğinin eşleşmesiyle belirlenir. Uzun dolaşım yarı ömre sahip antikorların tümörlerde birikimi enjeksiyondan günler sonra gerçekleşir. Bu sebeple kısa yarı ömre sahip ${ }^{111} \mathrm{C},{ }^{118} \mathrm{~F}$ veya ${ }^{68} \mathrm{Ga}$ gibi radyonüklidler yerine ${ }^{89} \mathrm{Zr},{ }^{64} \mathrm{Cu}$ ve ${ }^{86} \mathrm{Y}$ gibi daha uzun yarı ömre sahip radyonüklidlerin kullanılmasını zorunlu kılar. $\mathrm{Bu}$ derlemede, uzun yarı ömre sahip olması ile immüno-PET görüntülemede yaygın olarak kullanılan ${ }^{89} \mathrm{Zr}\left(\mathrm{t}_{1 / 2}=3.3\right.$ gün, $\% 22,7 \beta^{+}, \mathrm{E}_{\beta+}$ ort. $=396 \mathrm{keV}$ ) radyonüklidi ile işaretlenmiş farmasötikler gözden geçirilmiş ve umut veren yeni seçenekler olarak uygulanabilirliği tartışılmıştır [16].

\subsection{Zr-89 Issaretli Antikorlar}

Immüno-PET olarak da adlandırılan radyoişaretli mAb'ler tümör hücrelerinin lokalizasyonunda ve tanısında ilgi çekici bir yöntemdir. Bu potansiyelin farkedilmesi onların görüntüleme ajanı olarak geliştirilmesinde geniş bir araştırma alanı yaratmıştır. ${ }^{89} \mathrm{Zr}$ radyonüklidi ile işaretli $\mathrm{mAb}$ 'ler kullanılarak PET görüntüleme, tümör hücrelerindeki lokalizasyonu ve ajanların afinitesini ölçmek için büyük bir potansiyel oluşturmaktadır [3]. Literatürde mAb'li konjugatlara ilişkin son beş yılda yapılan pre-klinik ve klinik çalışmalar aşağıda yer almaktadır.

\subsubsection{CD20 Hedefleme}

Glikosile edilmiş fosfoprotein(CD20); B hücreli lenfomaların (DLBCL), tüylü hücreli löseminin, B hücreli kronik lenfositik löseminin ve melonom hücrelerinin yüzeyinde eksprese edilir [2]. Klinik çalışmada, ${ }^{89} \mathrm{Zr}$ işaretli anti-CD20 'ya yönelik bir mAb olan rituksimab diffüz büyük $\mathrm{B}$ hücreli lenfoma (DLBCL)'lı altı hastaya enjekte edilmiştir ve ${ }^{89} \mathrm{Zr}$ Rituximab'in tümör hücrelerine tutulumu biyopsi sonucunda alınan değerler ile olumlu bir bağlantıyı ortaya koymuştur [17].

\subsubsection{CD44 Hedefleme}

Bir glikoprotein olan CD44 birçok kanser türünde ve kanser kök hücrelerinde aşırı eksprese edilir. Preklinik çalışmalara baktığımızda; CD44'e özgü bir antikor olan scFV-Fc ${ }^{89} \mathrm{Zr}$ radyonüklidi ile işaretlemişler ve PET kullanarak CD44-pozitif kanserleri görüntülemek için değerlendirmişlerdir. In vivo biyodağılım verileri ${ }^{89} \mathrm{Zr}$ DFO-scFv-Fc-CD44'ün insan meme kanser hücreleri üzerinde yüksek tümör tutulumu ve tümör/kan oranı göstermişdir. Bu sonuçlar 1şığında CD44-pozitif tümörlü hastalar için PET görüntüleme ajanı olarak ${ }^{89} \mathrm{Zr}$-DFOscFv-Fc-CD44'ün klinik araştırmaları garanti etmişlerdir [18]. Klinik çalışmalara baktığımızda, CD44 eksprese eden kat1 maligniteli 65 hastada ${ }^{89} \mathrm{Zr}-\mathrm{rG} 7356$ radyofarmasötiği Pullanılarak değerlendirilmişdir. ${ }^{89} \mathrm{Zr}-\mathrm{RG} 7356$ erken klinik gelişimde immüno-PET kullanımını desteklemekte olduğu görülmüştür [19].

\subsubsection{EGFR Hedefleme}

Epidermal büyüme faktörü reseptörü (EGFR), pek çok epitelyal tümörde fazla miktarda eksprese edilir. Baş ve boyun, meme, akciğer, mesane ve kolon kanseri başta olmak üzere çeşitli tümör tipinin farklılaşması, proliferasyonu ve hayatta kalmasında çok önemli bir rol oynar. Bu hedef ile ilgili yapılan pre-klinik çalışmalarda; EGFR monoklonal antikor ${ }^{89} \mathrm{Zr}$-İmgatuzumab'ın çeşitli ksenograft modellerinde tümör tutulumu üzerindeki etkisini incelenmiş ve EGFR eksprese eden tümörlerin etkili bir şekilde görüntülendiğini tespit etmişlerdir [20]. Nimotuzumab, EGFR'ye yüksek affinite gösteren insanlaştırılmış bir mAb'dir. ${ }^{89} \mathrm{Zr}$-DFO-Nimotuzumab'ın farmakokinetiği, biyodağılımı, mikroPET görüntülemesi, radyasyon dozimetrisi ve tümör taşıyan/tümör taşımayan farelerde normal doku toksisitesi değerlendirilmişdir. Fare ksenograftlarda PET görüntüleri yüksek tutulum göstermekle birlikte normal dokuda toksisite göstermediği belirlenmiştir [21]. ${ }^{89} \mathrm{Zr}$ DFO-nimotuzumab'ın gliomada aşırı eksprese edilen EGFR hedefli in vivo davranışı, PET/BT görüntüleme kullanılarak subkutan U87MG (EGFR-pozitif) tümörleri taşıyan farelerde incelenmiştir. $\mathrm{Bu}$ konjugatyüksek radyokimyasal verim $(>\% 90)$, radyokimyasal saflık $(>\% 99)$ ve spesifik aktivite göstermiştir. ${ }^{89} \mathrm{Zr}-\mathrm{DFO}-$ Nimotuzumab'in gliomada EGFR durumunu değerlendirmede faydalıdır [22]. ${ }^{89} \mathrm{Zr}$-DFO-Setuksimab farelerde in vivo çalışmalar ile PET'te değerlendirilmiştir. EGFR ekspresyonu ile korelasyon gösteren bu radyofarmasötik, setuksimab ile tedavi sırasında HNSCC hastalarında direnci izlemek için yararlı olabileceği kanıtlanmışdır [23]. Yeni bir antiEGFR antikoru olan MAb806, malign mezotelyoma (MM) hücreli ksenograftlarda ch806 kullanılarak biyodağılımı ve görüntüleme çalışmaları gerçekleştirdi. ${ }^{89} \mathrm{Zr}$ ile işaretlenen bu konjugat MM tümörlerinde PET 
görüntülerinde spesifik hedeflenme göstermiş̧tir [24]. Yapılan klinik çalışmalarda, ileri kolorektal kanserli on hastada, ${ }^{89} \mathrm{Zr}$-Setuksimab PET görüntüleme ile biyodağılımı ve tümör tutulumu değerlendirilmişdir. Tümör lezyonlarında ${ }^{89} \mathrm{Zr}$-Setuksimab tutulumuon hastanın altısında tespit edilmiş ve ${ }^{89} \mathrm{Zr}$-Setuksimabın tümör tutulumu PET görüntüleme ile teşhis edimiştir [25]. İlerlemiş baş ve boyun skuamöz hücre karsinomlu (LAHNSCC)'li on yedi hastaya ${ }^{89} \mathrm{Zr}$-Setuksimab enjekte edilerek üç ve altı veya dört ve yedi gün sonra PET/BT görüntüleri elde edilmișdir. Sonuç olarak, ${ }^{89} \mathrm{Zr}$ Setuksimab PET görüntüleme, LAHNSCC'de hastalar arası geniş çeşitlilik göstermektedir [26]. ${ }^{89} \mathrm{Zr}$ Panitumumab metastatik kolon kanseri olan üç hastaya i.v enjekte edildi. Fare çalışmalarından elde edilen veriler ile eşleşerek güvenli görünmektedir ve dozimetri tahminleri klinik görüntüleme ile uyum içindedir [27].

\subsubsection{HER2 Hedefleme}

İnsan epidermal büyüme faktörü reseptörü 2 (HER2/neu), meme kanserinde aşırı eksprese edilir ve tümör büyümesi, anjiyogenez ve uzak metastaz ile ilişkilidir. Trastuzumab, bir anti-HER2 mAb olup HER2 (+) meme kanseri tedavisinde kullanılır. Preklinik çalışamalara baktığımızda; İleri seviye HER2 pozitif meme kanseri tedavisinde kullanılan trastuzumabemtansinin (T-DM1) ${ }^{89} \mathrm{Zr}$ ile işaretlendi ve ${ }^{89} \mathrm{Zr}$-DFO-TDM1'in tümör ve normal doku tutulumun1 ${ }^{89} \mathrm{Zr}$-DFOtrastuzumab ile karşılaştırılmışdır. ${ }^{89} \mathrm{Zr}$-DFO-T-DM1, ${ }^{89} \mathrm{Zr}$-DFO-Trastuzumab'a göre az farklılıkla HER2'ye yüksek afinite göstermiştir ve ${ }^{89} \mathrm{Zr}$-DFO-T-DM1'nin HER2-pozitif meme kanseri iletimini değerlendirmek için yararlı bir prob olduğu sonucuna varılmıştır [28]. HER2 (+) meme kanseri ksenograftları taşıyan farelerde Ado-trastuzumab emtansin (T-DM1) tedavisine erken tepkiyi izlemek için ${ }^{89} \mathrm{Zr}$-Pertuzumab görüntülemenin fizibilitesini araştırmışlardır. ${ }^{89} \mathrm{Zr}-\mathrm{DFO}-\mathrm{Bz}-\mathrm{NCS}$ Pertuzumab başarı ile konjuge edilmiş ve bu konjugat HER2 (+) tümörlerin iyi bir şekilde tanımlandığını gösterilmişdir [29]. Anaplastik troid kanserinde (ATC) HER2 ekspresyon durumunu saptamak için HER2'ye özgü mAb olan pertuzumab ${ }^{89} \mathrm{Zr}$ ile işaretlenmiştir. PET görüntüleri subkutan ve ortotopik ATC modellerinde değerlendirilmiş ve tümör tutulumunın umut verici olduğu gösterilmişdir [30]. Pro, Ala ve Ser (PASilasyon) doğal amino asitlerin genetik fizyon yoluyla elde edilen antikorların antijen bağlayıcı fragmanlarını (Fab) ${ }^{89} \mathrm{Zr}$ radyonüklidi ile işaretlemişler ve yüksek kontrastlı PET tümör görüntülemesi elde etmişlerdir. ${ }^{89} \mathrm{Zr}$-Df-FabPAS200 yüksek in vivo stabilite ve tümör tutulumu gösterdiği tespit edilmiştir [31]. Antikor ilaç konjugatı (ADC) trastuzumab-DM1'in (T-DM1) DFO veya DFO* (farklı şelatörlere sahip DFO) ile konjugasyonusonucu ${ }^{89} \mathrm{Zr}$ ile işaretlenmiştir ve karşılaştırmasını yapmışlardır. HER2 bağlanma afiniteleri SK-BR-3 insan meme kanseri hücreleri veya SKOV-3 insan yumurtalık kanseri hücreleri kullanılarak ölçülmüştür. ${ }^{89} \mathrm{Zr}-\mathrm{DFO}$ *-T-DM1, ${ }^{89} \mathrm{Zr}$-DFO-T-DM1'e göre daha kararlı kompleştiği ve daha yüksek stabilite nedeniyle daha iyi görüntü elde edilmiştir [32]. DFO, DFO* ve DFOcyclo* şelatörleri tek başına ve trastuzumaba konjugasyondan sonra stabilitesi
${ }^{89} \mathrm{Zr}$-immuno-PET'te karşılaştırılması HER2 eksprese eden SKOV-3 hücre ksenograftları farelerde değerlendirilmişdir. ${ }^{89} \mathrm{Zr}$ işaretli DFOcyclo* ve DFOcyclo*-trastuzumab, mevcut yaygın olarak kullanılan ${ }^{89} \mathrm{Zr}$-DFO-trastuzumab'dan daha yüksek in vitro ve in vivo stabilite göstermiştir [33]. ${ }^{89} \mathrm{Zr}$-DFO-TDM1 insan meme ksenograftları olan farelerde mikroPET/BT ile değerlendirilmişdir. Sonuçlar ${ }^{89} \mathrm{Zr}$ DFO-T-DM1 içeren PET'in HER2 yanıtını tahmin edebileceğini göstermektedir [34]. Trastuzumab'a konjuge silikon-rodamin (SiR) bağlantılı lineer desferrikrom (LDFC) $)^{89} \mathrm{Zr}$ ile radyoişaretlenmişdir. ${ }^{89} \mathrm{Zr}$ SiR-LDFC-Trastuzumab dişi NCr çiplak farelerde görüntülenmişdir. Başarılı bir radyoişaretleme gerçekleşmiş ve ${ }^{89} \mathrm{Zr}$-SiR-LDFC-trastuzumab'ın in vivo standart DFO konjugatına benzer şekilde davrandığ 1 bulunmuştur [35]. Farklı şelatör kullanarak p-SCN-BnDesferrioxamine (SCN-Bn-DFO) trastuzumab ile konjuge edildi ve ${ }^{89} \mathrm{Zr}$ ile işaretlenmişdir. Biyodağılım ve PET görüntüleme sonuçları ${ }^{89} \mathrm{Zr}-\mathrm{SCN}-\mathrm{Bn}-\mathrm{DFO}-$ trastuzumab'ın PDX fare modellerinde HER2-pozitif tümörleri başarıyla tespit etmiştir [36]. ${ }^{89} \mathrm{Zr}-\mathrm{DFO}-$ Trastuzumab-PTX (Paklitaksel) konjugat1 HER2(+) meme kanser hücreleri üzerinde değerlendirilmişdir. $\mathrm{Bu}$ radyokonjugatın terapötik uygulamalarda kullanım potansiyelinin yüksek olduğu gösterilmişdir [37]. Klinik çalışamalara baktığımızda; ${ }^{89} \mathrm{Zr}$-trastuzumabın tümör tutulumunın HER2(+) 34 ve HER2(-) 16 kadın hastanın meme kanserini ayırt edip edemeyeceğini değerlendirilmişdir. PET görüntüleri elde edildikten sonra tümör yükünün HER2 durumunu karakterize etme potansiyeline sahip olduğu belirtilmişdir [38]. HER2 negatif primer meme kanserli hastalarda HER2 pozitif metastazları tespit edip edemeyeceğini saptamak için ${ }^{89} \mathrm{Zr}$-Trastuzumab PET/BT uygulanmıșdır. ${ }^{89} \mathrm{Zr}$ Trastuzmab PET/BT'nin HER2-negatif primer meme kanserli hastalarda HER2-pozitif metastazlar1 saptadı $\breve{g}_{1}$ gösterilmişdir [39]. Metastatik HER2(+) özofagogastrik adenokarsinomlu (EGA) on hastada ${ }^{89} \mathrm{Zr}$-Trastuzumab değerlendirilmişdir. $\quad \mathrm{Bu} \quad$ radyofarmasötiğin enjeksiyonundan beş-sekiz gün sonra optimum görüntüleme süresi ile yüksek çözünürlükte görüntüler elde edilmişdir [40]. HER2 durumu standart çalışma ile belirlenemediğinde ${ }^{89} \mathrm{Zr}$-Trastuzumab PET'in tanısal anlayışı destekleyip destekleyemeyeceğini klinik olarak araştırmışlardır. Kaydedilen 20 meme kanserli hastada ${ }^{89} \mathrm{Zr}$-Trastuzumab PET tedavi kararını desteklenmișdir [41]. HER2 pozitif meme kanserli hastalarda ${ }^{89} \mathrm{Zr}$ Pertuzumab PET/BT'nin güvenliği araştırılmışdır. Bu ilk insan çalışması, ${ }^{89} \mathrm{Zr}$-pertuzumab PET/BT ile birden fazla malignite bölgesini görüntüleme başarılı bulunmuşdur [42]. Tümör ile ilgili HER2 ekspresyonunun moleküler görüntülemesi için PASillenmiş bir Fab parçasının ( ${ }^{89} \mathrm{Zr}$-Df-HER2-FabPAS200) ilk klinik değerlendirilmesini yapmışlardır. ${ }^{89} \mathrm{Zr}$-Df-HER2-Fab-PAS200 metastatik meme kanserli hastada küçük tümör lezyonlarının görüntülenmesine olanak sağlamış ve uygun kan temizlenmesi göstermiştir [43].

\subsubsection{VEGF Hedefleme}


Vasküler endotelyel büyüme faktörü (VEGF), anjiyogenezde önemli bir rolü vardır ve VEGF-A tümörün büyümesi ve hematojen metastazların oluşumu ile ilişkilendirilir [44]. Pre-klinik çalışamlara baktığımızda; ${ }^{89} \mathrm{Zr}$-Df-R(Ramucirumab), prostat kanserli fare modelinde VEGFR-2 ekspresyonu tespiti PET görüntüleme ile yapılmıștır. Bu konjugatın prostat kanserinde VEGFR-2 ekspresyonunu açıklayabildiği kanıtlanmıştır [45]. Klinik çalışmalara baktığımızda, Beyin tümörlü diffüz intrinsik pontin gliomlu (DIPG) çocuklarda ${ }^{89} \mathrm{Zr}$-işaretli bevacizumabın tümör tutulumu tespit edilmiştir. PET taraması ile değerlendirilen ${ }^{89} \mathrm{Zr}$ Bevacizumab tümör birikimi DIPG'li çocuklarda uygulanabileceğini gösterdi [46]. Metastatik renal hücreli karsinomlu hastalarda (mRCC)VEGF-A bağlayıcı PET izleyici olan ${ }^{89} \mathrm{Zr}$-Bevacizumab'ın tümör tutulumu saptanmıştır. ${ }^{89} \mathrm{Zr}$-Bevacizumab PET taramaları 22 hastada 125 değerlendirilebilir tümör lezyonunu görselleştirdi ve tümör tutulumunın mRCC'de yüksek olduğunu belirlenmişdir [47].

\subsubsection{HER3 Hedefleme}

HER3, epidermal büyüme faktörü reseptörü (EGFR) ailesinin bir üyesidir ve kolorektal kanser (CRC) dahil olmak üzere çeşitli karsinomlarda aşırı eksprese edilir. Preklinik çalışmalara baktığımızda, HER3/RH7777 ksenograftlarını taşıyan farelerde in vivo biyodağılım çalışmas $1,{ }^{89} \mathrm{Zr}$-Mab\#58'in (antibodi) tümör birikiminin, PET tarafından başarılı bir şekilde görüntülendiğini göstermişlerdir [48]. ${ }^{89} \mathrm{Zr}$ işaretli anti-HER3 antikor mAb3481kullanılarak PET ile lapatinib tedavisinden sonra in vivo HER3 tümör durumu meme ve mide kanseri hücre hatlarında değerlendirilmişdir. ${ }^{89} \mathrm{Zr}-\mathrm{mAb} 3481$ ile yüksek, HER3'e özgü tümör tutulumu gösterdiği PET ile tespit edilmiştir [49]. İnsan ksenograft tümör taşıyan farelerde GSK2849330 mAb HER3'e yönelik ${ }^{89} \mathrm{Zr}$ ile radyoişaretlenmiştir. ${ }^{89} \mathrm{Zr}$-GSK2849330 enjeksiyondan 144 saat sonra tümör tutulumu HER3 eksprese eden tümörlerde ayırt edici olmuştur [50].

\subsubsection{PSMA Hedefleme}

Prostata özgü membran antijeni (PSMA), tip II transmembran glikoproteindir. En iyi karakterize edilmiş onkojenik hedeflerden biridir ve PSMA'ya yönelik antikorlar fonksiyonel olarak tümöre özgüdür. Klinik çalışmalarda, beyin tümörlerinin neovasküler yapısının değerlendirilmesi için ${ }^{89} \mathrm{Zr}$-Df-IAB2M üç hastada PET tarama gerçekleştirilmişdir. İleri derecede glioma ve metastatik beyin tümörlerinde PSMA ekspresyonu ${ }^{89} \mathrm{Zr}$ Df-IAB2M ile PET görüntüleme ile açıkça görselleştirildi [51]. ${ }^{89} \mathrm{Zr}$-Df-IAB2M prostat kanseri olan onüç ve diğer ürolojik kanserli dört hastada PET görüntüleme çalışması yapılmışdır. ${ }^{89} \mathrm{Zr}$-Df-IAB2M ile 24-48 saatte hem kemik hem de lenf nodu metastazları tespit edilmişdir [52]. Metastatik prostat kanseri olan hastalarda anti-prostat spesifik mebran antijen minibodi ${ }^{89} \mathrm{Zr}$-Desferrioksamin-IAB2M $\quad\left({ }^{89} \mathrm{Zr}-\mathrm{IAB} 2 \mathrm{M}\right) \quad$ doz çalışması yapılmıştır. ${ }^{89} \mathrm{Zr}-\mathrm{IAB} 2 \mathrm{M}$ güvenlidir, uygun biyolojik dağılım ve kinetik gösterdiği belirlenmişdir [53].

\subsubsection{MET Hedefleme}

c-MET antikoru Onartuzumab, ilerlemiş küçük akciğer kanserinin (NSCLC) tedavisi için tasarlanmış insanlaştırılmış bir monoklonal antikordur. Preklinik çalışmalarda, ${ }^{89} \mathrm{Zr}$-Onartuzumab NSCLC tümörleri taşıyan farelerde PET taraması yapılmıştır. Sonuçlar, ${ }^{89} \mathrm{Zr}$-Onartuzumab PET'in c-MET seviyelerindeki ilgili değişiklikleri etkili bir şekilde ayırt ettiğini ve potansiyel olarak c-MET durumunu izlemek için klinik olarak kullanılabileceğini göstermişdir [54]. Amivantamab, TNBC dahil olmak üzere çeşitli kanserlerde aşırı eksprese edilen EGFR ve c-MET'i hedefleyen spesifik bir antikordur. ${ }^{89} \mathrm{Zr}$-DFO-Amivantamab akciğer kanser ksenograftlarında PET ile değerlendirilmişdir. ${ }^{89} \mathrm{Zr}$ DFO-Amivantamab, EGFR ve c-MET'i birlikte ifade eden tümörlerde en yüksek tutulumu göstermişdir [55]. Hepatosit büyüme faktörü (HGF) bağlayıcı antikoru rilotumumab (AMG102) ${ }^{89} \mathrm{Zr}$ ile yüksek radyokimyasal verim ve saflıkta işaretlenerek elde edilmişdir. Şelatör olarak p-SCN-Bn-DFO kullanılmışdır. ${ }^{89} \mathrm{Zr}$-p-SCN-BnDFO-AMG102, U87MG (HGF-pozitif, MET-pozitif), MKN45 (HGF-negatif, MET-pozitif) ve dört murin ksenograftta PET görüntüleme yapılmıştır. Bu konjugat HGF-pozitif ksenograftlarda tümörlerde seçici tutulum gösterdiği tespit edilmiştir. Dört farklı mide kanseri hastasından türetilmiş ksenograft modelinde ise düşük HGF seviyelerine karş1lık düşük tutulum gösterdiği saptamıştır [56]. MKN-45 mide karsinom hücre ksenograftları taşıyan dişi atimik çıplak farelerde ${ }^{89} \mathrm{Zr}$ DFO-Bn-NCS-onartuzumab ve ${ }^{89} \mathrm{Zr}$-DFO-azepinonartuzumab ile görüntülenmişdir. Her iki radyofarmasötiğin yüksek tümör tutulumu gösterdiği ortaya konulmuştur [57].

\subsubsection{PD-1/PD-L1 Hedefleme}

$\mathrm{T}$ ve pro-B hücrelerinde bulunan programlanmış hücre ölüm proteini 1 (PD-1) ve programlanmış hücre ölümü ligand1 1 (PD-L1) blokajı güçlü anti-tümör immün yanıtları ortaya çıkarır ve bunların antikorları melanom, böbrek, küçük hücreli olmayan akciğer kanseri tedavisi için FDA'dan onay almıştır. Pre-klinik çalışmalarda, pembrolizumab PD-1'i hedefleyen mAb'dir. ${ }^{89} \mathrm{Zr}$ Deferoksamin(Df)-pembrolizumab farelerde ve sıçanlarda T-hücresi kontrol noktası reseptör ekspresyonunu ve lokalizasyonunu görüntülemek içinfaydalı olduğu gösterilmişdir [58]. ${ }^{89} \mathrm{Zr}-\mathrm{Df}-\mathrm{KN} 035$ immüno-PET probunu LN229 ksenograftları taşıyan çıplak farelerde PD-L1 seviyelerini izlemek ve değerlendirmek için immüno-PET çalışmaları yapılmışdır. Yeni bir anti-PD-L1 antikor bazlı prob olan ${ }^{89} \mathrm{Zr}-\mathrm{Df}-\mathrm{KN} 035, \quad$ PD-L1 ekspresyonunun invazif olmayan in vivo değerlendirmesinin uygulanabilirliğini gösterilmişdir [59]. Nivolumab (BMS-936558), çoklu kanser türlerinin tedavisi için onaylanmış mAb'dir. ${ }^{89} \mathrm{Zr}$ Nivolumab sağlıklı insan olmayan primatlarda (NHP) PET ile değerlendirilmiştir ve dalağa spesifik biyodağılım gösterir [60]. ${ }^{89} \mathrm{Zr}$-Df-nivolumab kullanılarak A549 tümör taşıyan farelerin PET ile tümör görüntülenmesi yapılmıştır. PD-1 yeni hedefli ajanların tasarımına ve geliştirilmesine yardımcı olabilecek bir radyofarmasötik olduğu tespit edilmiştir [61]. İnsan A375M melanom hücreleri ile ksenograftlanmış fareler 
${ }^{89} \mathrm{Zr}$-Pembrolizumab uygulandıktan sonra PET görüntülemesi yapılmıştır. Sonuçlar ${ }^{89} \mathrm{Zr}$ Pembrolizumab'ın tüm vücut dağılımının değerlendirilmesini sağlayabileceğini göstermiştir [62]. 49 yaşında erkek hastadan alınan tümör numunesi NOD/SCID farelerine implante edilmiştir. Yüksek PDL1 seviyeleri gösteren tümörde önemli ölçüde yüksek ${ }^{89} \mathrm{Zr}$-atezolizumab tutulumunı ortaya çıkarmıştır [63]. ${ }^{89} \mathrm{Zr}$-Df-Avelumab (Ave), meme kanseritaşıyan farelerde değerlendirilmek üzere PET görüntülemesi yapılmıştır. $\mathrm{Bu}$ radyofarmasötiğin özgünlüğünü ve uygulanabilirliğini destekleyen kanıtlar ortaya konulmuştur [64].

\subsection{Zr-89 İşaretli Nanopartiküller}

Antikorlar, şeklinde büyük bir protein olup, disülfat bağlarıyla bir arada tutulan iki ağır-iki hafif polipeptit zincirinden oluşur. İki sabit bölge ( $\mathrm{CH} 2$ ve $\mathrm{CH} 3)$, bir kesişme bölgesi ve yalnızca ağır zincirden oluşan değişken bölgeden (VHH; antijen bağlama bölgesi) oluşmaktadır. Antijen bağlama bölgesi olan bu kısma nanokor (nanobodi; VHH) ad1 verilir. Nanobodilerin antikorlara göre avantajlı olması oval şekillerinden dolayı antikorların ulaşamadığı bölgelere bağlanmayı ve dokuya daha iyi nüfuz etmesini sağlamaktadır [65]. Son y1llarda, nanopartiküllerin radyonüklidlerle işaretlenmesi ve bunların teşhis ve tedavi radyofarmasötiği olarak araştırılması artmıștır ve büyük bir potansiyel oluşturmaktadır [20]. Bol silanol gruplarına sahip içi boş mezogözenekli silika nanosferleri (HMsNs) çok yönlülükleri nedeniyle biyomedikal alanlarda oldukça aranan bir silika nanopartiküldür. Preklinik çalışmalara bakıldığında; HMsNs, CD47 protein kümesine sahip kırmızı kan hücresi membranı (Rm) ile kaplanarak ${ }^{89} \mathrm{Zr}$ ile işaretlenmiş ve 26 tümör ksenograft taşıyan farelerde biyodağılım çalışmaları yapılmıştır. ${ }^{89} \mathrm{Zr}-\mathrm{HMsN}$ sradyofarmasötiği başarı bir şekilde sentezlenmiş ve düşük toksisite gösterdiği saptanmıştır. Rm- ${ }^{89} \mathrm{Zr}$ HMSN'ler kandaki dolaşımda tümör bölgesine etkili bir şekilde ulaşmıştır ve çeşitli hastalıkların teşhisi ve tedavisi için iyi bir araç olacağını doğrulanmıştır [66]. Metal oksit nanoyapıların şelatörsüz radyoişaretlemesi için $\mathrm{Gd}_{2} \mathrm{O}_{3}$ nanorodları kullanılmış ve PET görüntüleri elde edilmiştir. ${ }^{89} \mathrm{Zr}_{-}-\mathrm{Gd}_{2} \mathrm{O}_{3}$-PEG'in $\mathrm{PET}$ görüntüleri başarılı bir şekilde gerçekleştirilmiştir [67]. UiO-66 nano ölçekli metal-organik çerçeve malzemeleri (nMOF) ${ }^{89} \mathrm{Zr}$ ile işaretlenerek polietilen glikol (Py-PGA-PEG) ile işlevselleştirilmişve üçlü negatif meme tümörlerinin hedeflenmesi için bir peptit ligandıyla (F3) nükleoline konjuge edilmiştir. ${ }^{89} \mathrm{Zr}-\mathrm{UiO}-66 / \mathrm{Py}-\mathrm{PGA}-\mathrm{PEG}-\mathrm{F} 3$ 'ün tümör seçici bir konjugat olduğu kanıtlanmıştır [68]. Mezogözenekli silika nanopartikülün (MSN) şelatör içermeyen Zr-89 ile işaretlenmesi PET görüntü kılavuzlu ilaç dağıtımını incelemek için yeni, basit ve doğru bir yoldur [69]. $\mathrm{WS}_{2} / \mathrm{WO}_{\mathrm{x}}$ nanodot tabakaları PEG ile modifiye edilmiş $\left(\mathrm{WS}_{2} / \mathrm{WO}_{\mathrm{x}}-\mathrm{PEG}\right)$ ve ${ }^{89} \mathrm{Zr}$ ile işaretlenmiştir. ${ }^{89} \mathrm{Zr}-\mathrm{WS}_{2} / \mathrm{WO}_{\mathrm{x}}-\mathrm{PEG}$ i.v uygulama üzerine tümörlerin in vivo görüntülenmesi veya derin yerleşimli drenaj lenf düğümü ağının haritalanması için mükemmel bir PET kontrast ajanı olduğu bulunmuştur [70]. Mangan oksit nanopartiküllerin $\left(\mathrm{Mn}_{3} \mathrm{O}_{4} @ \mathrm{PEG}\right)$ şelatörsüz ${ }^{89} \mathrm{Zr}$ işaretlemesi yapılmış ve bugüne kadar yaygın nanopartiküller ile karşılaştırıldığında ${ }^{89} \mathrm{Zr}$ $\left(\mathrm{Mn}_{3} \mathrm{O}_{4} @ \mathrm{PEG}\right)$ lenf düğümlerinde baskın yüksek tutulumu gösterdiği PET ile görüntülenmiştir [71]. Ultra ince cRGDY-konjuge floresan silika nanopartikülleri (C noktaları) PEG ile işlevselleştirip ${ }^{89} \mathrm{Zr}$ ile radyoişaretlenmiştir. ${ }^{89} \mathrm{Zr}$ işaretli ultra ince hibrid organik-inorganik partikül moleküler hedefli kanser görüntüleme için umut verici bir PET izleyici olduğu tespit edilmişdir [72]. PET ile lipoplex nanosistemlerinin (LNP) tümörde birikiminin izlenmesi araştırılmıştır. ${ }^{89} \mathrm{Zr}$-LNP altına kıyasla farelerde yüksek karaciğer ve düşük böbrek tutulumu gözlenmiştir. Enjeksiyondan iki saat sonra tümörde birikim gözlenmiştir. Kanser gen tedavisi bağlamında görüntü kılavuzu olarak bu LNP'ler umut verici olduğu saptanmışdır [73]. Seryum oksit NP (CONP), ${ }^{89} \mathrm{Zr}$ ile işaretlenmiş ve ${ }^{89} \mathrm{Zr}$-CONP'ler yüksek radyokimyasal verimlilik ıgöstererek biyodağılım için potansiyeli umut verici olduğu saptanmışdir [74]. Çok küçük silika nanopartiküller HER2 için yüksek tümör hedefleme göstermiştir. Bunun için geliştirilen ${ }^{89} \mathrm{Zr}$ DFO-scFv-PEG-Cy5-C' radyofarmasötik hem tümörlü doku görüntüleme ajanı olarak hem de yararlı bir ilaç taşıyıcı potansiyeli olduğu tespit edilmiştir [75].

\subsection{Zr-89 İşaretli Diğer Bileşikler}

Afibody molekülleri, monoklonal antikorları taklit eden çok sayıda hedef proteine veya peptide yüksek afinite ile bağlanmak üzere tasarlanmış küçük, proteinlerdir ve bu nedenle antikor mimetrikleri ailesinin bir üyesidir [76]. Preklinik çalışmalar 1şı̆̆ında, EGFR bağlayıcı bir afibody molekülü (Z $\left.\mathrm{Z}_{\mathrm{EGFR}}: 2377\right)$, DFO şelatörü ile konjuge edilerek ${ }^{89}$ Zrradyonüklidi ile işaretlenmiştir. EGFR eksprese eden A431 epidermoid karsinom taşıyan ksenograft farelerde ${ }^{89} \mathrm{Zr}-\mathrm{DFO}-\mathrm{Z}_{\mathrm{EGFR}}: 2377$ spesifik tutulum göstermiştir. ${ }^{89} \mathrm{Zr}-\mathrm{DFO}-\mathrm{Z}_{\mathrm{EGFR}}$ :2377, enjeksiyondan 48 saat sonra anti-EGFR antikoru ${ }^{89} \mathrm{Zr}$ DFO-setuksimab'dan daha yüksek tümör-organ oranları sağlamıştır. EGFR ifade eden tümörler net bir şekilde görüntülenebilmiştir [77]. EGFR'ye özgü afibody molekülünü ( $\left.Z_{\mathrm{EGFR}}: 03115\right),{ }^{89} \mathrm{Zr}$ ile radyoişaretlenmiş ve subkutan tümörleri taşıyan farelerde biyolojik dağılım sonuçları araştırılmıştır. ${ }^{89} \mathrm{Zr}$-Deferoxamine$\mathrm{Z}_{\mathrm{EGFR}}$ :03115 konjugatının in vivo çalışmaları PET'te net tümör görüntülenmesine izin vermiş ve bu radyofarmasötiğin tümör tutulumu EGFR'ye özgü olduğu ortaya konulmuştur [78]. Hsp90 inhibisyonunun neden olduğu HER3 değişikliklerini kantitatif olarak değerlendiren afibody olan $\mathrm{Z}_{\text {HER3 }}: 8698 \quad{ }^{89} \mathrm{Zr}$ ile radyoişaretlenmiştir. $\quad{ }^{89} \mathrm{Zr}$-ZHER3:8698 radyofarmasötiği meme kanser ksenograft modellerinde yapılan in vivo çalışmalar sonucunda elde edilen PET görüntüleri HER3 ekspresyonu hakkında bilgi sağlamıştır [79]. ${ }^{89} \mathrm{Zr}$ işaretli yeni bir HER2 afibody, ${ }^{89} \mathrm{Zr}$ DFO-MAL-Cys-MZHER2 sentezlenerek insan yumurtalık kanser hücresi taşıyan farelerde PET ile görüntülenmiştir. $\mathrm{Bu}$ yeni radyofarmasötik tatmin edici işaretleme verimi ve radyokimyasal saflıkla kolayca hazırlanmış ve HER2 ekspresyonunu saptamak için potansiyel bir aday olduğu ortaya konulmuştur [80]. 


\section{Sonuç}

Son zamanlarda ${ }^{89} \mathrm{Zr}$-PET görüntülemeyle ilgili preklinik ve klinik çalışmaların sayısı önemli derecede artmıştır ve bu nedenle antikor, nanopartikül ve diğer bileşik bazlı immüno-PET radyofarmasötiklerin potansiyeline ait son beş yılda yapılan çalışmalar bu derlemede bir başlık altında toplanmıştır.

Monoklonal antikorlar kullanılarak CD20, CD44, EGFR, HER2, VEGFR-A, HER3, PSMA, CAIX, MET, GPC3 ve PD-1/PD-L1 ve TEM-1 hedeflenmişdir. CD20 hedeflenmesine yönelik ${ }^{89} \mathrm{Zr}$-rituximab DLBCL'li hastalarda klinik olarak denenmiştir ve tümör hücrelerine tutulumu biyopsi sonucunda alınan değerler ile olumlu bir bağlantıyı ortaya koymuştur. CD44 hedeflemede ${ }^{889} \mathrm{Zr}$-DFO-scFv-Fc-CD44 insan meme kanser hücreleri üzerinde yüksek tümör tutulumu ve tümör/kan oranı göstermiştir. CD44 pozitif dokularda. ${ }^{89} \mathrm{Zr}-\mathrm{RG} 7356$ erken klinik gelişimde immüno-PET kullanımını desteklemekte olduğu görülmüştür. EGFR hedeflemede; ${ }^{89} \mathrm{Zr}$-Nimotuzumab fare ksenograftlarında, ${ }^{89} \mathrm{Zr}$ İmgatuzumab EGFR (+) dokularda ve ${ }^{89} \mathrm{Zr}-\mathrm{MAb} 806$ MM'li farelerde incelenmiştir. EGFR eksprese eden tümörlerin etkili bir şekilde görüntülendiği tespit edilmiştir. ${ }^{89} \mathrm{Zr}$-Setuksimab ve ${ }^{89} \mathrm{Zr}$-Panitumumab'ın klinik ve preklinik çalışmaları yapılmıştır ve bu radyofarmasötiklerin kullanımı umut vericidir. HER2 hedeflemede ${ }^{89} \mathrm{Zr}$-Trastuzumab'ın klinik ve preklinik çalışmaları yayınlanmıştır ve EGA, HER2 (+) mem kanserinde yapılan çalışmada yüksek spesifik aktivite ile tutulum göstermiştir. ${ }^{89} \mathrm{Zr}-\mathrm{T}-\mathrm{DM} 1 \mathrm{HER} 2(+)$; meme kanserli ksenograftlarda, ${ }^{89} \mathrm{Zr}$-pertuzumab; troid ve meme tümörlü farelerde, ${ }^{89} \mathrm{Zr}$-Fab-PAS200; klinik ve preklinik olarak memede ve ${ }^{89} \mathrm{Zr}$-DFO-TrastuzumabPTX; meme kanserli ksenograft farelerde incelenmiştir. ${ }^{89} \mathrm{Zr}$-DFO-Trastuzumab-PTX, ${ }^{89} \mathrm{Zr}$-trastuzumab'a göre daha yüksek afinite ile tümör hücrelerine hedeflenmiştir. $\mathrm{Bu}$ radyofarmasötikler ile yapılan çalışmalar sonucunda büyük bir potansiyele sahip olduğu gösterilmiştir. VEGF hedeflemede, ${ }^{89} \mathrm{Zr}$-Bevacizumab klinik çalışmalarda DIPG'li çocuklarda, RCC kanserinde araştırılmış ve başarılı bir radyofarmasötik olduğu kanıtlanmıştır. ${ }^{89} \mathrm{Zr}$ Ranibizumab prostat kanserli farelerde ideal görüntüleme ajanı olarak belirtilmiştir. HER3 hedefleme, preklinik olarak ${ }^{89} \mathrm{Zr}-\mathrm{Mab} \# 58,{ }^{89} \mathrm{Zr}-\mathrm{mAb} 3481$ ve ${ }^{89} \mathrm{Zr}$ GSK2849330 radyofarmasötikleri değerlendirilmiş ve HER3 eksprese eden tümörlerde ayırt edici oldukları tespit edilmiştir. PSMA hedefleme, ${ }^{89} \mathrm{Zr}$-Df-IAB2M klinik olarak glioma, metastatik beyin tümörlü hastalarda, prostat kanserli hastalarda PSMA ekspresyonunu başarılı bir şekilde görüntülemiştir. CAIX hedeflemede, ${ }^{89} \mathrm{Zr}$-DFO-girentuximab klinik olarak çok iyi PET görüntüleri elde edilmesini sağlamıştır. MET hedeflemede, ${ }^{89} \mathrm{Zr}$-Onatuzumab: NSCLC, ${ }^{89} \mathrm{Zr}$-Amivantamab: akciğer kanseri, ${ }^{89} \mathrm{Zr}$-DFOazepin-onartuzumab: mide kanseri ve ${ }^{89} \mathrm{Zr}$ Rilotumumab: $\mathrm{MET}(+)$ dokulu ksenograftlı farelerde başarılı bir PET görüntüleme elde edilmiştir. GPC3 hedeflemede, ${ }^{89} \mathrm{Zr}-\mathrm{N}$-suc-Df-ERY974 yüksek tümör tutulumu ile iyi görüntüleme probu olarak değerlendirilmiştir. TEM-1 hedeflemede, sarkom hastalarında ${ }^{89} \mathrm{Zr}$-Ontuxizumab'ın tümörde yüksek radyofarmasötik tutulumunu göstermişlerdir. Yapılan bu $\mathrm{mAb}$ hedefli radyofarmasötikler arasında PD-1/PD-L1 hedefleme son zamanlarda büyük ilgi odağ olmuştur. ${ }^{89} \mathrm{Zr}$-Df-Pembrolizumab, ${ }^{89} \mathrm{Zr}$-Df-KN035, ${ }^{89} \mathrm{Zr}$ Nivolumab, ${ }^{89} \mathrm{Zr}$-Atezolizumab ve ${ }^{89} \mathrm{Zr}$-Df-Avelumab radyofarmasötikleri değerlendirilmiştir. T-hücresi kontrol noktası reseptör ekspresyonunu ve lokalizasyonunu görüntülemek için faydalıdırlar. Nanopartiküller kullanılarak antikorların ulaşamadıkları bölgelere hedeflenen radyofarmasötikler olarak oldukça büyük potansiyele sahiptirler. $\mathrm{HMsNs}, \mathrm{Gd}_{2} \mathrm{O}_{3}, \mathrm{nMOF}$, $\mathrm{WS}_{2} / \mathrm{WO}_{\mathrm{x}}, \mathrm{Mn}_{3} \mathrm{O}_{4}, \mathrm{C}$ noktalar1, LNP, CONP gibi nanopartiküller kullanılarak ${ }^{89} \mathrm{Zr}$ ile radyoişaretleme yapılmıştır. Tümör bölgesine etkili bir şekilde ulaşan ve çeşitli hastalıkların teşhisi ve tedavisi için iyi bir araç olacağı doğrulanan nanotıp radyofarmasötikler büyük bir potansiyel oluşturmaktadır. Bunlar ile birlikte afibodilerin de ${ }^{89} \mathrm{Zr}$ ile radyoişaretlemesi büyük bir potansiyel oluşturmaktadır.

Son beş yılda yapılan klinik öncesi ve klinik çalışmalar ışığında, PET ile kanser görüntülemede kullanılan radyofarmasötikler içinde ${ }^{89} \mathrm{Zr}$ radyofarmasötiklerinin geliştirilmesi çok büyük bir potansiyel ifade etmektedir ve edecektir.

\section{Referanslar}

1. Loud, J.T, Murphy, J, Cancer Screening and Early Detection in the 21st Century, Seminars in Oncology Nursing, 2017, 33(2), 121-128.

2. Van de Watering, F.C, Rijpkema, M, Perk, L, Brinkmann, U, Oyen, W.J, Boerman, O.C, Zirconium-89 labeled antibodies: a new tool for molecular imaging in cancer patients, BioMed Research International, 2014, 203601

3. Kasbollah, A, Eu, P, Cowell, S, Deb, P, Review on production of $89 \mathrm{Zr}$ in a medical cyclotron for PET radiopharmaceuticals, Journal of Nuclear Medicine Technology, 2013, 41(1):35-41.

4. Vugts, D.J, Visser, G.W, van Dongen, G.A, 89Zr-PET radiochemistry in the development and application of therapeutic monoclonal antibodies and other biologicals, Current Topics in Medicinal Chemistry, 2013, 13(4), 446-57

5. Bhatt, N.B, Pandya, D.N, Wadas, T.J, Recent Advances in Zirconium-89 Chelator Development, Molecules, 2018, 23(3), 638.

6. Severin, G.W, Engle, J.W, Barnhart, T.E, Nickles, R.J, 89Zr radiochemistry for positron emission tomography, Medical Chemistry, 2011, 7(5), 389-94.

7. Vermeulen, K, Vandamme, M, Bormans, G, Cleeren, F, Design and Challenges of Radiopharmaceuticals, Seminars in Nuclear Medicine, 2019, 49(5), 339-356.

8. Van Dongen, G.A, Huisman, M.C, ve ark., ${ }^{89} \mathrm{Zr}$-immuno-PET for imaging of long circulating drugs and disease targets: why, how and when to be applied?, The Quarterly Journal of Nuclear Medicine and Molecular Imaging, 2014, 59(1), 18-38.

9. Zhang, Y, Hong, H, Cai, W, PET tracers based on Zirconium-89, Current Radiopharmaceuticals, 2011, 4(2), 131-9.

10. Yoon, J.K, Park, B.N, Ryu, E.K, An, Y.S, Lee, S.J, Current Perspectives on 89Zr-PET Imaging, International Journal of Molecular Sciences, 2020, 21(12), 4309

11. Heskamp, S, Raavé, R, Boerman, O, Rijpkema, M, Goncalves, V, Denat, $\mathrm{F},{ }^{89} \mathrm{Zr}$-Immuno-Positron Emission Tomography in Oncology: State-of-the-Art $89 \mathrm{Zr}$ Radiochemistry, Bioconjugate Chemistry, 2017, 28(9), 2211-2223.

12. La, M.T, Tran, V.H, Kim, H.K, Progress of Coordination and Utilization of Zirconium-89 for Positron Emission Tomography (PET) Studies, Nuclear Medicine and Molecular Imaging, 2019, 53(2), 115-124

13. Deri, M.A, Zeglis, B.M, Francesconi, L.C, Lewis, J.S, PET imaging with 89Zr: from radiochemistry to the clinic, Nuclear Medicine and Biology, 2013, 40(1), 3-14. 
14. Sahmaran, T, Bayburt, M, Pozitron Emisyon Tomografi - Bilgisaya Tomografi (Pet-Bt) Uygulamalarında Hastanın Aldığı Radyasyon Dozunun Belirlenmesi, Kafkas Üniversitesi Fen Bilimleri Enstitüsü Dergisi, 2020, 13(1), 58-63.

15. Wadsak, W, Mitterhauser, M, Basics and principles of radiopharmaceuticals for PET/BT, European Journal of Radiology, 2010, 73(3), 461-9.

16. Aluicio-Sarduy, E, Ellison, P.A, Barnhart, T.E, Cai, W, Nickles, RJ, Engle, J.W, PET radiometals for antibody labeling, Journal of Labelled Compounds and Radiopharmaceuticals, 2018, 61(9), 636651

17. Jauw, Y.W, Zijlstra, J.M, ve ark., Performance of ${ }^{89} \mathrm{Zr}$-LabeledRituximab-PET as an Imaging Biomarker to Assess CD20 Targeting: A Pilot Study in Patients with Relapsed/Refractory Diffuse Large B Cell Lymphoma, PLoS One, 2017, 12(1), e0169828.

18. Diebolder, P, Mpoy, C, Scott, J, et al, Preclinical Evaluation of an Engineered scFv-Fc Targeting Human CD44, Journal of Nuclear Medicine, 2020, 120.249557.

19. Menke-van der Houven van Oordt, C.W, Gomez-Roca, C, ve ark., First-in-human phase I clinical trial of RG7356, an anti-CD44 humanized antibody, in patients with advanced, CD44-expressing solid tumors, Oncotarget, 2016, 7(48), 80046-80058.

20. Pool, M, Kol, A, Lub-de Hooge, M.N, Gerdes, C.A, de Jong, S, de Vries, E.G, Terwisscha van Scheltinga, A.G, Extracellular domain shedding influences specific tumor uptake and organ distribution of the EGFR PET tracer 89Zr-imgatuzumab, Oncotarget, 2016 , 7(42):68111-68121.

21. Chekol, R, Solomon, V.R, ve ark., 89Zr-nimotuzumab for ImmunoPET imaging of epidermal growth factor receptor I, Oncotarget, 2018, 9(24):17117-17132.

22. Tang, Y, Hu, Y, ve ark., A radiopharmaceutical 89Zr-DFO nimotuzumab for immunoPET with epidermal growth factor receptor expression in vivo, Nuclear Medicine and Biology, 2019, 70, 23-31.

23. Benedetto, R, Massicano, AVF, ve ark., 89Zr-DFO-Cetuximab as Molecular Imaging Agent to Identify Cetuximab Resistance in Head and Neck Squamous Cell Carcinoma, Cancer Biotherapy and Radiopharmaceuticals, 2019, 34(5), 288-296.

24. Chia, P.L, Parakh, S, ve ark., Targeting and Efficacy of Nove mAb806-Antibody-Drug Conjugates in Malignant Mesothelioma, Pharmaceuticals (Basel), 2020, 13(10), 289.

25. Menke-van der Houven van Oordt, C.W, Gootjes, E.C, ve ark., 89Zrcetuximab PET imaging in patients with advanced colorectal cancer, Oncotarget, 2015, 6(30), 30384-93.

26. Even, A.J, Hamming-Vrieze, O, ve ark., Quantitative assessment of Zirconium-89 labeled cetuximab using PET/BT imaging in patient with advanced head and neck cancer: a theragnostic approach, Oncotarget, 2017, 8(3), 3870-3880.

27. Lindenberg, L, Adler, S, ve ark., Dosimetry and first human experience with 89Zr-panitumumab, American Journal of Nuclear Medicine and Molecular Imaging, 2017, 7(4), 195-203.

28. Al-Saden, N, Lam, K, Chan, C, Reilly, RM, Positron-Emission Tomography of HER2-Positive Breast Cancer Xenografts in Mice with 89Zr-Labeled Trastuzumab-DM1: A Comparison with 89Zr Labeled Trastuzumab, Molecular Pharmaceutics, 2018, 15(8), 3383 3393.

29. Massicano, A.V.F, Lee, S, ve ark., Imaging of HER2 with [89Zr] pertuzumab in Response to T-DM1 Therapy, Cancer Biotherapy and Radiopharmaceuticals, 2019, 34(4), 209-217.

30. Wei, W, Jiang, D, Rosenkrans, Z.T, ve ark., HER2-targeted multimodal imaging of anaplastic thyroid cancer, American Journa of Cancer Research, 2019, 9(11), 2413-2427.

31. Mendler, C.T, Gehring, T, Wester, H.J, Schwaiger, M, Skerra, A 89Zr-Labeled Versus 124I-Labeled aHER2 Fab with Optimized Plasma Half-Life for High-Contrast Tumor Imaging In Vivo, The Journal of Nuclear Medicine, 2015, 56(7), 1112-8.

32. Cho, H, Al-Saden, N, Lam, H, Möbus, J, Reilly, R.M, Winnik, M.A A comparison of DFO and DFO* conjugated to trastuzumab-DM1 for complexing $89 \mathrm{Zr}$ - In vitro stability and in vivo microPET/BT imaging studies in NOD/SCID mice with HER2-positive SK-OV-3 human ovarian cancer xenografts, Nuclear Medicine and Biology, 2020, 84-85, 11-19.

33. Raavé, R, Sandker, G, ve ark., Direct comparison of the in vitro and in vivo stability of DFO, DFO* and DFOcyclo* for $89 \mathrm{Zr}$ immunoPET, European Journal of Nuclear Medicine and Molecular Imaging, 2019, 46(9), 1966-1977.
34. Al-Saden, N, Cai, Z, Reilly, R.M, Tumor uptake and tumor/blood ratios for $89 \mathrm{Zr}$-DFO-trastuzumab-DM1 on microPET/BT images in NOD/SCID mice with human breast cancer xenografts are directly correlated with HER 2 expression and response to trastuzumab-DM1, Nuclear Medicine and Biology, 2018, 67, 43-51.

35. Ahn, S.H, Thach, D, ve ark., Linear Desferrichrome-Linked SiliconRhodamine Antibody Conjugate Enables Targeted Multimodal Imaging of HER2 in Vitro and in Vivo, Molecular Pharmaceutics, 2019, 16(3), 1412-1420.

36. Kristensen, L.K, Christensen, C, ve ark., Site-specifically labeled 89Zr-DFO-trastuzumab improves immuno-reactivity and tumo uptake for immuno-PET in a subcutaneous HER2-positive xenograft mouse model, Theranostics, 2019, 9(15), 4409-4420.

37. Jang, J.H, Han, S.J, Kim, J.Y, Kim, K.I, Lee, K.C, Kang, C.S, Synthesis and Feasibility Evaluation of a new Trastuzumab Conjugate Integrated with Paclitaxel and $89 \mathrm{Zr}$ for Theranostic Application Against HER2-Expressing Breast Cancers, ChemistryOpen, 2019, 8(4), 451-456.

38. Dehdashti, F, Wu, N, ve ark., Evaluation of 89Zr-trastuzumabPET/BT in differentiating HER2-positive from HER2-negative breast cancer, Breast Cancer Research and Treatment, 2018, 169(3), 523-530.

39. Ulaner, G.A, Hyman, D.M, ve ark., Detection of HER2-Positive Metastases in Patients with HER2-Negative Primary Breast Cancer Using 89Zr-Trastuzumab PET/BT, The Journal of Nuclear Medicine, 2016, 57(10), 1523-1528

40. O'Donoghue, J.A, Lewis, J.S, ve ark., Pharmacokinetics, Biodistribution, and Radiation Dosimetry for 89Zr-Trastuzumab in Patients with Esophagogastric Cancer, The Journal of Nuclear Medicine, 2018, 59(1), 161-166.

41. Bensch, F, Brouwers, A.H, ve ark, 897r-trastuzumab PET supports clinical decision making in breast cancer patients when HER2 status cannot be determined by a standard workup, European Journal of Nuclear Medicine and Molecular Imaging, 2018, 45(13), 2300-2306.

42. Ulaner, G.A, Lyashchenko, S.K, ve ark., First-in-Human Human Epidermal Growth Factor Receptor 2-Targeted Imaging Using 89ZrPertuzumab PET/BT: Dosimetry and Clinical Application in Patients with Breast Cancer, The Journal of Nuclear Medicine, 2018, 59(6), 900-906.

43. Richter, A, Knorr, K, ve ark., First In-Human Medical Imaging with a PASylated 89Zr-Labeled Anti-HER2 Fab-Fragment in a Patient with Metastatic Breast Cancer, Nuclear Medicine and Molecular Imaging, 2020, 54(2), 114-119.

44. Vural, P, Fizyolojik ve Patolojik Anjiogenezde Vasküler Endotelyal Büyüme Faktörünün Rolü, Türk Klinik Biyokimya Dergisi, 2018, 16(1), 53-62.

45. Li, M, Jiang, D, ve ark., Immuno-PET imaging of VEGFR-2 expression in prostate cancer with $89 \mathrm{Zr}$-labeled ramucirumab, American Journal of Cancer Research, 2019, 9(9), 2037-2046.

46. Jansen, M.H, Veldhuijzen van Zanten, S.E.M, ve ark., Molecular Drug Imaging: 89Zr-Bevacizumab PET in Children with Diffuse Intrinsic Pontine Glioma, The Journal of Nuclear Medicine, 2017, 58(5), 711716 .

47. Oosting, S.F, Brouwers, A.H, ve ark., 89Zr-bevacizumab PET visualizes heterogeneous tracer accumulation in tumor lesions of renal cell carcinoma patients and differential effects of antiangiogenic treatment, The Journal of Nuclear Medicine, 2015, 56(1), 63-9.

48. Yuan, Q, Furukawa, T, ve ark., Immuno-PET Imaging of HER3 in a Model in which HER3 Signaling Plays a Critical Role, PLoS One, 2015, 10(11), e0143076.

9. Pool, M, Kol, A, de Jong, S, de Vries, E.G.E, Lub-de Hooge, M.N Terwisscha van Scheltinga, A.G.T, 89Zr-mAb3481 PET for HER3 tumor status assessment during lapatinib treatment, MAbs, 2017, 9(8), 1370-1378.

50. Alsaid, H, Skedzielewski, T, ve ark., Non-invasive imaging assessment of the biodistribution of GSK2849330, an ADCC and CDC optimized anti HER3 $\mathrm{mAb}$, and its role in tumor macrophage recruitment in human tumor-bearing mice, PLoS One, 2017, 12(4), e0176075

51. Matsuda, M, Ishikawa, E, ve ark., Potential use of prostate-specific membrane antigen (PSMA) for detecting the tumor neovasculature of brain tumors by PET imaging with $89 \mathrm{Zr}$-Df-IAB2M anti-PSMA mini body, Journal of Neuro-Oncology, 2018, 138(3), 581-589. 
52. Joraku, A, Hatano, K, ve ark., Phase I/IIa PET imaging study with 89Zr labeled anti-PSMA mini body for urological malignancies, Annals of Nuclear Medicine, 2019, 33(2), 119-127.

53. Pandit-Taskar, N, O'Donoghue, J.A, ve ark., First-in-Human Imaging with $89 \mathrm{Zr}$-Df-IAB2M Anti-PSMA Mini body in Patients with Metastatic Prostate Cancer: Pharmacokinetics, Biodistribution, Dosimetry, and Lesion Uptake, The Journal of Nuclear Medicine, 2016, 57(12), 1858-1864.

54. Pool, M, Terwisscha van Scheltinga, A.G.T, Kol, A, Giesen, D, de Vries, E.G.E, Lub-de Hooge, M.N, 89Zr-Onartuzumab PET imaging of c-MET receptor Dynamics, European Journal of Nuclear Medicine and Molecular Imaging, 2017, 44(8), 1328-1336.

55. Cavaliere, A, Sun, S, ve ark., Development of $89 \mathrm{Zr}-\mathrm{DFO}$ amivantamab bispecific to EGFR and c-MET for PET imaging of triple-negative breast cancer, European Journal of Nuclear Medicine and Molecular Imaging, 2020, https://doi.org/10.1007/s00259-02004978-6.

56. Price, E.W, Carnazza, K.E, ve ark., 89Zr-DFO-AMG102 ImmunoPET to Determine Local Hepatocyte Growth Factor Protein Levels in Tumors for Enhanced Patient Selection, The Journal of Nuclear Medicine, 2017, 58(9), 1386-1394.

57. Klingler, S, Fay, R, Holland, J.P, Light-Induced Radiosynthesis of 89Zr-DFO-Azepin-Onartuzumab for Imaging the Hepatocyte Growth Factor Receptor, The Journal of Nuclear Medicine, 2020 61(7), 1072-1078.

58. England, C.G, Ehlerding, E.B, ve ark., Preclinical Pharmacokinetics and Biodistribution Studies of 89Zr-Labeled Pembrolizumab, The Journal of Nuclear Medicine, 2017, 58(1), 162-168.

59. Li, D, Cheng, S, ve ark., Immuno-PET Imaging of 89Zr Labeled AntiPD-L1 Domain Antibody, Molecular Pharmaceutics, 2018, 15(4), 1674-1681.

60. Cole, E.L, Kim, J, ve ark., Radiosynthesis and pre-clinical PET evaluation of 89Zr-nivolumab (BMS-936558) in healthy non-human primates, Bioorganic \& Medicinal Chemistry, 2017, 25(20), 54075414.

61. England, C.G, Jiang, D, ve ark., 89Zr-labeled nivolumab for imaging of T-cell infiltration in a humanized murine model of lung cancer, European Journal of Nuclear Medicine and Molecular Imaging, 2018, 45(1), 110-120.

62. Van der Veen, E.L, Giesen, D, Pot-de Jong, L, Jorritsma-Smit, A, De Vries, E.G.E, Lub-de Hooge, M.N, 89Zr-pembrolizumab biodistribution is influenced by PD-1-mediated uptake in lymphoid organs, Journal for ImmunoTherapy of Cancer, 2020, 8(2), e000938.

63. Vento, J, Mulgaonkar, A, ve ark., PD-L1 detection using $89 Z$ ratezolizumab immuno-PET in renal cell carcinoma tumorgrafts from a patient with favorable nivolumab response, Journal for ImmunoTherapy of Cancer, 2019, 7(1), 144.

64. Li, M, Ehlerding, E.B, ve ark., In vivo characterization of PD-L1 expression in breast cancer by immuno-PET with $89 \mathrm{Zr}$-labeled avelumab, American Journal of Translational Research, 2020, 12(5), 1862-1872.

65. Karakaş, N, Öztürk, İ, Tosyalı, S, Bay, S, Nanobodies: Diagnostic and Therapeutic Antibody Fragments, Acta Oncologica Turcica, 2018 51(2), 240-250.

66. Lee, J.Y, Vyas, C.K, ve ark., Red Blood Cell Membrane Bioengineered Zr-89 Labelled Hollow Mesoporous Silica Nanosphere for Overcoming Phagocytosis, Scientific Reports, 2019, 9(1), 7419

67. Cheng, L, Shen, S, ve ark., Chelator-Free Labeling of Metal Oxide Nanostructures with Zirconium-89 for Positron Emission Tomography Imaging, ACS Nano, 2017, 11(12), 12193-12201.

68. Chen, D, Yang, D, ve ark., In Vivo Targeting and Positron Emission Tomography Imaging of Tumor with Intrinsically Radioactive MetalOrganic Frameworks Nanomaterials, ACS Nano, 2017, 11(4), 43154327.

69. Chen, F, Goel, S, ve ark., In Vivo Integrity and Biological Fate of Chelator-Free Zirconium-89-Labeled Mesoporous Silica Nanoparticles, ACS Nano, 2015, 9(8), 7950-9.

70. Cheng L, Kamkaew A, Shen S, ve ark., Facile Preparation of Multifunctional WS2 /WOx Nanodots for Chelator-Free $89 \mathrm{Zr}$ Labeling and In Vivo PET Imaging, Small, 2016, 12(41), 5750-5758.
71. Zhan, Y, Ehlerding, E.B, et al., Intrinsically Zirconium-89-Labeled Manganese Oxide Nanoparticles for In Vivo Dual-Modality Positron Emission Tomography and Magnetic Resonance Imaging, Journal of Biomedical Nanotechnology, 2018, 14(5), 900-909.

72. Chen, F, Ma, K, et al, Target-or-Clear Zirconium-89 Labeled Silica Nanoparticles for Enhanced Cancer-Directed Uptake in Melanoma: A Comparison of Radiolabeling Strategies, Chemistry of Materials, 2017, 29(19), 8269-8281.

73. Hajdu, I, Makhlouf, A, et al, A 89Zr-labeled lipoplex nanosystem for image-guided gene delivery: design, evaluation of stability and in vivo behavior, International Journal of Nanomedicine, 2018, 13, 7801-7818.

74. McDonagh, P.R, Sundaresan, G, Yang, L, Sun, M, Mikkelsen, R, Zweit, J, Biodistribution and PET imaging of 89-zirconium labeled cerium oxide nanoparticles synthesized with several surface coatings, Nanomedicine, 2018, 14(4), 1429-1440.

75. Chen, F, Ma, K, et al, Ultrasmall targeted nanoparticles with engineered antibody fragments for imaging detection of HER2 overexpressing breast cancer, Nature Communications, 2018, 9(1) 4141

76. Tolmachev, V, Orlova, A, Affibody Molecules as Targeting Vectors for PET Imaging, Cancers (Basel), 2020, 12(3), 651.

77. Garousi, J, Andersson, K.G, et al, PET imaging of epidermal growth factor receptor expression in tumors using 89Zr-labelled ZEGFR:2377 affibody molecules, International Journal of Oncology, 2016, 48(4), 1325-32.

78. Burley, T.A, Da Pieve, C, et al, Affibody-Based PET Imaging to Guide EGFR-Targeted Cancer Therapy in Head and Neck Squamous Cell Cancer Models, The Journal of Nuclear Medicine, 2019, 60(3), 353-361.

79. Martins, C.D, Da Pieve, C, et al, HER3-Mediated Resistance to Hsp90 Inhibition Detected in Breast Cancer Xenografts by Affibody-Based PET Imaging, Clinical Cancer Research, 2018, 24(8), 1853-1865.

80. Xu, Y, Wang, L, et al, Synthesis of a novel 89Zr-labeled HER2 affibody and its application study in tumor PET imaging, EJNMMI Research, 2020, 10(1), 58.

http://edergi.cbu.edu.tr/ojs/index.php/cbusbed isimli yazarın CBU-SBED başlıklı eseri bu Creative Commons Alınt1-Gayriticari4.0 Uluslararas1 Lisans1 ile lisanslanmıştır. 